\title{
Water Transfer Diminishes Root Competition Between Peach and Tall Fescue
}

\author{
D.M. Glenn' and W.V. Welker ${ }^{2}$ \\ Appalachian Fruit Research Station, Agricultural Research Service, U.S. Department of Agriculture, \\ Kearneysville, WV 25430
}

Additional index words. apparent root surface potential, Festuca arundinaceae, Prunus persica, rhizotron, soil pressure potential, split-root

\begin{abstract}
Seedling 'Tennessee Natural' peach [Prunus persica (L.) Batsch] trees were grown in a series of five greenhouse experiments to determine how peach root development was affected by the interaction of soil pressure potential and the presence of Kentucky-31 (K-31) tall fescue (Festuca arundinaceae Schreb.). Peach trees were grown in split-root rhizotrons that had four separate root growth sections. When two of the four sections had live sod (LS) and two remained bare soil (BS), there was no effect of the LS on peach root development when the trees were irrigated daily. Peach root development was reduced in BS and LS treatments when soil pressure potential was less than $\mathbf{- 0 . 0 6}$ MPa. In contrast, when trees were grown in rhizotrons that had all four sections with either LS or a killed K-31 sod (KS), peach root development was reduced in the LS treatment compared to the KS treatments when irrigated daily or when soil pressure potential reached $-\mathbf{0 . 0 3} \mathrm{MPa}$. The apparent root surface water potential of peach trees in the LS treatment was $-\mathbf{0 . 4}$ MPa lower than that in the KS treatment under daily irrigation due to the interference of the K-31 tall fescue. In two additional experiments using peach trees with BS in all four sections, we maintained three sections at field capacity and allowed one section to dry to $\mathbf{- 0 . 0 6}$ to 1.5 MPa. During the night, when transpiration was low, water was transferred to the dry soil section via the peach root system from the three wet soil sections. It appears that the root system of peach can maintain root development in the presence of tall fescue by transferring water from regions of high water availability to those of low availability.
\end{abstract}

In the sloping topography typical of some productive orchard sites, a grass drive middle is necessary to prevent soil erosion and facilitate equipment traffic in the orchard. Peach tree growth, however, is affected adversely by the proximity of sod (Welker and Glenn, 1989) and the presence of weeds or cover crops in the tree row (Skroch and Shribbs, 1986). Interference with peach growth by interspecific competition is due primarily to reduced availability of soil water and nutrients to the peach root system (Glenn and Welker, 1991). 'Kentucky-31' (K-31) tall fescue has also been implicated as having an allelopathic potential (Putnam and Tang, 1986), although this has not been shown with peach. Phosphorus uptake may be enhanced in apple (Malus domestica Borkh.) through a grass association that facilitates a mycorrhizal association with the apple roots (Atkinson, 1983). However, in peach, we have shown that the presence of tall fescue roots reduces peach fine root development (Glenn and Welker, 1989). Our objectives in this work were to: 1) determine what soil water conditions were necessary to promote peach root development in monoculture and in association with tall fescue; 2) examine the influence of tall fescue on peach root development; and 3) evaluate the potential for peach roots in moist soil to transfer water to peach roots in dry soil.

\section{Methods and Materials}

Five greenhouse studies were conducted from 1987 to 1991. Seedling peach trees ('Tennessee Natural') were grown in splitroot rhizotrons (Glenn and Welker, 1991). Briefly, seedlings with 1-cm-diameter stems were planted in the center section of boxes with four sections $(52 \times 15 \times 50 \mathrm{~cm}, 1 \times \mathrm{w} \times \mathrm{d})$. The center section was $15 \times 15 \times 50 \mathrm{~cm}(1 \times \mathrm{w} \times \mathrm{d})$. A plastic partition embedded $2 \mathrm{~cm}$

Received for publication 20 July 1992. Accepted for publication 18 Dec. 1992. The cost of publishing this paper was defrayed in part by the payment of page charges. Under postal regulations, this paper therefore must hereby be marked advertisement solely to indicate this fact.

${ }^{1}$ Soil Scientist.

${ }^{2}$ Plant Physiologist. deep into the soil contained the surface irrigation water in each section of the rhizotron. The soil used was a Hagerstown silt loam (mixed, Mesic, Typic, Hapludalf). A soil water release curve was developed using five subsamples of the soil (Fig. 1).

Development of root mass (Study 1). Before planting the trees, a K-31 sod (LS) was established in two sections chosen at random from the four-section rhizotron. The two remaining sections were maintained vegetation-free (BS). The sod was planted in Feb. 1987, and the trees were planted in April. The design was a randomized block design with six replications of each four-section rhizotron testing BS vs. LS. The mean root length density (cm root/ $\mathrm{cm}^{3}$ soil) was determined in each section from nine horizontal soil cores $\left(218 \mathrm{~cm}^{3}\right)$ collected at 9,27 , and $45 \mathrm{~cm}$ on center measured from the central section where the tree was planted and at 9-, 27, and 45-cm depths measured on center. The roots were elutriated (Smucker et al., 1982) and peach root length (in centimeters) was determined using the modified line intersect method of Tennant (1975). Peach roots counted with the fescue sod treatment were distinguished from grass roots by color differences and branching habit. For data analysis, the mean root treatment length density $(\mathrm{cm}$ root $/ \mathrm{cm}^{3}$ soil) was calculated using nine samples/section and the mean of the duplicate treatments in each replicate. Root length density was determined for fine peach roots $(<1 \mathrm{~mm}$ in diameter, FRLD) and large peach roots ( $21 \mathrm{~mm}$ in diameter, LRLD). Analysis of variance was based on a paired $t$ test for FRLD and LRLD at the end of the study. Tree growth was not a response variable. Tree diameter at a $15-\mathrm{cm}$ height was $19.7 \mathrm{~mm} \pm 0.7 \mathrm{~mm}$ (mean $\pm \mathrm{SD}$ ) at the end of the study in July.

Irrigation frequency (Study 2). Before planting the trees, a K31 sod (LS) was established in two sections chosen at random from the four-section rhizotron. The two remaining sections were left vegetation-free (BS). The sod was planted in Feb. 1988, and the trees were planted April. The design was a split-plot with each rhizotron as a replication. The main plot was the presence or absence of sod (LS vs. BS) and the subplots were frequency of irrigation (daily vs. when soil pressure potential reached -0.06 $\mathrm{MPa}$ ). During the study, the soil water pressure potential of the 


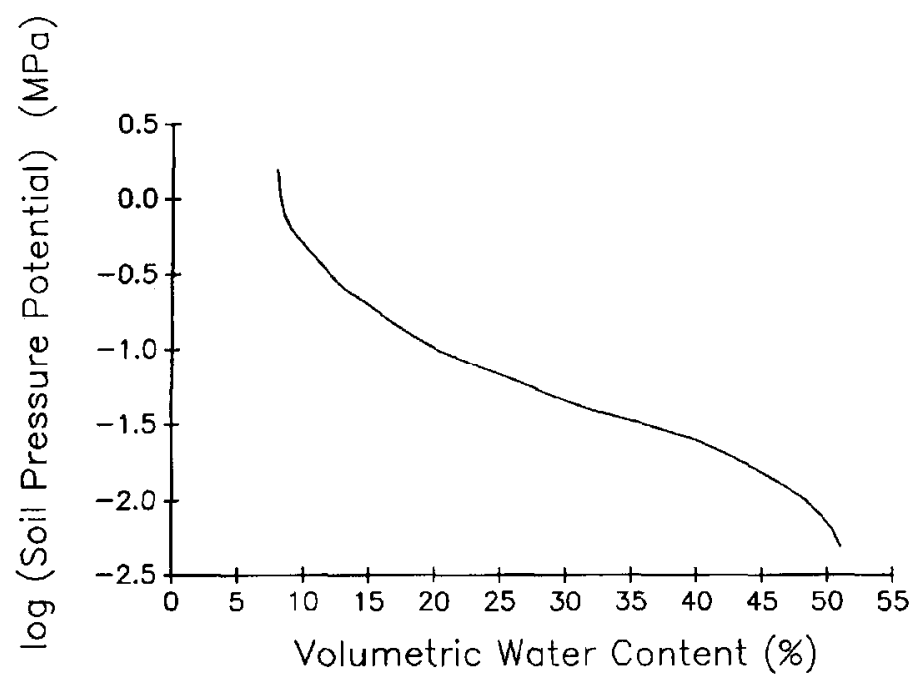

Fig. 1. Relationship of soil pressure potential to volumetric water content for the ' $A$ ' horizon of the Hagerstown silt loam.

daily irrigated treatment never exceeded $-0.01 \mathrm{MPa}$. The interval of irrigation at $0.06 \mathrm{MPa}$ varied from 2 weeks to 3 days. Tensiometers were installed in the center of all rhizotron sections and monitored daily. Six replications were used. Peach root length density was determined in each section as described in Study 1. For data analysis, the mean peach root length density was calculated using nine samples/subplot. Peach FRLD and LRLD were measured at the end of the study in August. Tree growth was not a response variable. Tree diameter at a $15-\mathrm{cm}$ height was $23.0 \pm 1.5$ $\mathrm{mm}(\mathrm{mean} \pm \mathrm{SD})$ at the end of the study.

Physiological response to irrigation scheduling (Study 3). A K31 sod was established in all sections of the rhizotrons before the trees were planted $(\mathrm{N}=12)$. The sod was planted in Feb. 1989. In March, the sod was killed (KS) with $N$-(phosphonomethyl) glycine (glyphosate) in all sections of half of the rhizotrons. Trees were planted in April. Tensiometers were installed in the center of one section of each rhizotron and monitored daily. There were two irrigation scheduling treatments: daily or periodic (when soil pressure potential reached $-0.03 \mathrm{MPa}$ ). A factorial arrangement of soil covers (KS vs. LS) and irrigation frequency (daily vs. periodic) was used in a randomized block design with three replications. Unlike Studies 1 and 2, all sections of each rhizotron were treated uniformly. All sections of each rhizotron were fertilized every 2 weeks with $20 \mathrm{~N}-4.4 \mathrm{P}-16.8 \mathrm{~K}$ fertilizer.

Leaves on each tree were counted every 2 to 3 weeks. Peach and grass root samples (two horizontal cores, $218 \mathrm{~cm}^{3}$ each) were collected from the central portion of a single section in each rhizotron at the termination of the study (15 Aug.). Root washing and counting were the same as described in Study 1. At the end of the study, above-ground oven-dried wood and leaf weight were determined.

On eight dates during the study, leaf water potential and stomatal conductance were measured on four midshoot leaves/tree and four grass leaves 0 to $3 \mathrm{~h}$ after solar noon in two of the three replications. Stomatal conductance was determined using a steadystate porometer (LI-COR model 1600, LI-COR, Lincoln, Neb.). After leaf conductance measurements, the leaf was covered with moist paper, detached, and its total leaf water potential measured in a pressure chamber,

The apparent root surface water potential was calculated according to Jones (1983):

$$
\Psi_{\mathrm{s}(\mathrm{D})}=\Psi_{\mathrm{l}(\mathrm{D})}-\Psi_{\mathrm{l}(\mathrm{C})}\left[\mathrm{g}_{\mathrm{l}(\mathrm{D})} / \mathrm{g}_{1(\mathrm{C})}\right]\left[\mathrm{A}_{(\mathrm{D})} / \mathrm{A}_{(\mathrm{C})}\right]
$$

where:

$\Psi_{\mathrm{s}(\mathrm{D})}=$ the apparent water potential at the root surface of the stressed treatment relative to the nonstressed treatment (MPa),

$\Psi_{1(\mathrm{D})}=$ leaf water potential of the stressed treatment (MPa),

$\Psi_{1(\mathrm{C})}=$ leaf water potential of the non-stressed ( $\left.\mathrm{MPa}\right)$ treatment,

$\mathrm{g}_{\mathrm{ID}}=$ stomatal conductance of the stressed treatment $\left(\mathrm{sm}^{-1}\right)$,

$\mathrm{g}_{\mathrm{I}(\mathrm{D})}=$ stomatal conductance of the nonstressed treatment $\left(\mathrm{sm}^{-1}\right)$,

$\mathrm{A}_{(\mathrm{D})}=$ leaf number of the stressed treatment, and

$\mathrm{A}_{(\mathrm{C})}=$ leaf number of the nonstressed treatment.

The killed sod daily irrigation treatment was used as the nonstressed treatment to calculate apparent peach root surface water potential. Calculations were performed by replication to account for changes in water relations with time. Leaf count at each measurement date was determined by interpolation from the leaf sampling dates before and after the measurement. The apparent grass root surface water potential was calculated using the LSdaily irrigation treatment as the nonstressed treatment. Grass leaf area was assumed to be the same for stressed and nonstressed treatments because monthly cutting weights were not significantly different (data not presented).

During the last 2 weeks of the study, soil water tension in the KS and LS periodic irrigation treatments was allowed to exceed the $0.03 \mathrm{MPa}$ limit before rewatering.

Water relations in watered and dry soil (Study 4). The rhizotron boxes were modified to minimize soil water movement between sections. Two plates of Plexiglas were placed at the opening in the center to each section. These plates were arranged in a "V" shape to leave a $1-\mathrm{cm}$ opening in the center, extending the entire height of each section. This opening would allow tree roots to grow in the central section and also grow into each side section. Potential soil water movement was reduced $93 \%$ because the area of soil exposed in the section was reduced from a $15-\mathrm{cm}$ width to a $1-\mathrm{cm}$ width. In this study, eight rhizotron boxes were filled with the Hagerstown silt loam and trees planted in only four of the rhizotrons. Trees were planted in Oct. 1989 and grown through May 1990. Beginning in April, only three of the four sections were watered on a daily basis where trees were present. The fourth section (dry) was irrigated when the soil pressure potential exceeded $-0.08 \mathrm{MPa}$ or the water column in the tensiometers broke.

The rhizotrons without trees had three sections maintained at $-0.001 \mathrm{MPa}$ and the fourth was allowed to dry to -0.06 to -0.08 $\mathrm{MPa}$ and then the soil surface was covered with aluminum foil to prevent evaporation. Two tensiometers were placed in the central portion of two sections in each rhizotron (one in wet soil, one in dry soil). The rhizotrons without trees served as controls to identify soil water movement between wet and dry sections of the rhizotron and to account for changes in tensiometer readings due to temperature and atmospheric pressure fluctuations.

On 7 days in April and May, when tree canopies were $\approx 2 \mathrm{~m}^{3}$, the canopies were enclosed by a black plastic bag in the late afternoon to stop transpiration, and the soil in the rhizotrons was covered with aluminum foil to stop evaporation. Tensiometer readings were made $3 \mathrm{~h}$ after enclosure of the trees and the following morning before the plastic bags were removed. Tensiometers in the wet and dry treatments of the rhizotrons without trees were measured at the same time. Peach root length density was determined in the dry sections from two horizontal soil cores $\left(218 \mathrm{~cm}^{3}\right)$ collected in the central portion, as described previously.

Regression analysis was used to relate the tensiometer readings in the afternoon to the following morning for rhizotrons with and without trees present. A t test was used to test the difference 
between slope and intercept $(P=0.05)$ for the two treatments.

Change in soil waterpotential during night (Study 5). The four rhizotron boxes used were constructed the same as in Study 4. Trees were planted in May 1991 and grown through Dec. 1991.

Beginning in December, three of the four sections were watered daily. The fourth section (dry) was irrigated when the soil pressure potential was in the range of -1.5 to $-2.0 \mathrm{MPa}$. The dry section was covered with aluminum foil to prevent evaporation. The trees were not covered at night, as in Study 4, due to the short days of December. Two soil psychrometers were installed in the center of the dry section of each rhizotron at a $15-\mathrm{cm}$ depth and soil water potential was measured daily at about 0700 and 1700 HR during December. A control was not used because Study 4 had shown that soil water movement between sections was negligible. On 17 Dec., a $1 \times 1 \times$ $50-\mathrm{cm}$ volume of soil was removed from the $1-\mathrm{cm}$ wide opening into the dry section. The soil removal created a gap between the three wet sections and the dry section. The roots were disturbed minimally by this action. The soil removal insured there was no soil water movement into the dry section. Data were then collected for the 3 consecutive days. Regression analysis was used to relate the soil water potential at $1700 \mathrm{HR}$ to the soil water potential at 0700 $\mathrm{HR}$ and a $t$ test was used to test if the slope and intercept differed from 1.0 and 0.0 , respectively.

\section{Results and Discussion}

Study 1. When a split-root system of BS and LS was kept at field capacity, FRLD and LRLD of peach were unaffected by the presence of K-31 grass roots (data not shown). In an earlier study (Glenn and Welker, 1989), we compared a similar split-root system and found that grass roots inhibited development of peach roots $<1 \mathrm{~mm}$ in diameter. The difference in the two studies apparently lies in the frequency of irrigation. In the present study, irrigation was daily, whereas in our previous study, the trees were irrigated when $90 \%$ of water available to the plant was depleted or every other day; thus, there was a potential for water stress to develop.

Table 1. Effect of bare soil and 'Kentucky 31' (K-31) tall fescue living sod irrigated either daily or at $-0.06 \mathrm{MPa}$ in a split-root system on peach root length density (Study 2 ).

\begin{tabular}{lccc}
\hline \hline & & \multicolumn{2}{c}{$\begin{array}{c}\text { Peach root length } \\
\text { density }\left(\mathrm{cm} \cdot \mathrm{cm}^{-3}\right)\end{array}$} \\
\hline $\begin{array}{l}\text { Soil cover } \\
\text { treatment }\end{array}$ & $\begin{array}{c}\text { Irrigation } \\
\text { frequency }\end{array}$ & $\begin{array}{c}\text { Roots }<1 \mathrm{~mm} \\
\text { diam. }\end{array}$ & $\begin{array}{c}\text { Roots } \geq 1 \mathrm{~mm} \\
\text { diam. }\end{array}$ \\
\hline Bare soil & Daily & $8.4 \mathrm{a}^{2}$ & $0.05 \mathrm{a}$ \\
& $-0.06 \mathrm{MPa}$ & $6.2 \mathrm{~b}$ & $0.04 \mathrm{ab}$ \\
Living sod & Daily & $8.2 \mathrm{a}$ & $0.05 \mathrm{a}$ \\
& $-0.06 \mathrm{MPa}$ & $5.9 \mathrm{~b}$ & $0.03 \mathrm{~b}$ \\
\hline${ }^{\mathrm{z}}$ Mean separation within columns by Duncan's multiple range test, $P \leq$ \\
0.05.
\end{tabular}

Study 2. When a split-root system of BS and LS was irrigated either daily or when the soil pressure potential reached -0.06 MPa, peach FRLD was reduced only when irrigation was delayed to a soil pressure potential of $-0.06 \mathrm{MPa}$ in both the BS and LS sections (Table 1). LRLD was reduced only when irrigation was delayed with a LS treatment. We concluded that, in a split-root system, the soil water tension was the controlling factor for peach root growth and that at soil pressure potentials greater than $-0.06 \mathrm{MPa}$, root growth was inhibited.

Study 3. When peach trees were grown in rhizotrons with a uniform soil cover (KS or LS) and irrigated either daily or when the soil water potential reached $-0.03 \mathrm{MPa}$, we found a different response from the LS treatment than expected from split-root studies. Unlike with split-root Studies 1 and 2, FRLD and LRLD were reduced by the presence of a uniform LS cover in the daily irrigated treatment; tree and leaf dry weight responded similarly (Table 2). Tree growth was further reduced when the LS was irrigated at $-0.03 \mathrm{MPa}$. The lack of agreement between Studies 1 and 2 vs. 3 suggested that partial cover by sod is less detrimental to peach trees than a uniform cover. We have shown that (Glenn and Welker, 1991), in a split-root system, the soil cover on $50 \%$ of soil surface can influence water use and $\mathrm{NO}_{3}-\mathrm{N}$ levels in the opposing $50 \%$ of the root volume and also root and top growth of peach, depending on the competitiveness of the cover crop and soil characteristics.

The presence of LS reduced peach FRLD compared to the daily irrigated $\mathrm{KS}$, even though the plots were irrigated daily. With KS, scheduling irrigation at $-0.03 \mathrm{MPa}$ did not reduce FRLD or LRLD appreciably compared to the daily irrigation of KS. However, with LS, both FRLD and LRLD were reduced when irrigation was delayed until the soil water potential reached $-0.03 \mathrm{MPa}$. The presence of living grass roots (LS) maintained the apparent root surface water potential of peach roots at $-0.4 \mathrm{MPa}$ when the soil water potential was between -0.04 and $-0.005 \mathrm{MPa}$ (Fig. 2). In the absence of living grass roots (KS), the apparent root surface water potential of peach roots was higher (less negative) for soil pressure potentials between -0.04 and $-0.005 \mathrm{MPa}$. When the soil pressure potential was less than $-0.04 \mathrm{MPa}$ (more negative), the apparent root surface water potential decreased for both the LS and KS. The apparent root surface water potential of grass roots was more than $-0.01 \mathrm{MPa}$ when the soil pressure potential was between -0.03 and $-0.005 \mathrm{MPa}$ (Fig. 3). The apparent root surface water potential of grass roots also decreased when the soil pressure potential was less than $-0.04 \mathrm{MPa}$.

Peach roots growing in the presence of K-31 tall fescue were subjected to continual stress even when the soil was at field capacity. These stress conditions apparently inhibited root initiation and growth. In split-root Studies 1 and 2, the lack of peachroot response to the presence of partial sod cover suggests a compensation within the root system when at least $50 \%$ of the root system is located in soil at field capacity and devoid of grass competition.

Study 4. We have shown previously (Glenn and Welker, 1991)

Table 2. The effect of soil cover (killed or living sod) and irrigation frequency (daily or when the soil water potential reached $-0.03 \mathrm{MPa}$ ) on peach tree total above-ground dry weight, leaf dry weight, and root length density.

\begin{tabular}{lccccc}
\hline & & Above-ground & Leaf dry & \multicolumn{2}{c}{ Root length density $\left(\mathrm{cm}^{\left.-\mathrm{cm}^{-3}\right)}\right.$} \\
Cover & Irrigation & dry tree wt (g) & wt (g) & $<1 \mathrm{~mm} \mathrm{diam.}$ & $\geq 1 \mathrm{~mm}$ diam. \\
\hline Living sod & Daily & $616 \mathrm{~b}^{2}$ & $198 \mathrm{~b}$ & $8.3 \mathrm{~b}$ & $0.04 \mathrm{~b}$ \\
& $-0.03 \mathrm{MPa}$ & $470 \mathrm{c}$ & $149 \mathrm{~b}$ & $5.3 \mathrm{c}$ & $0.02 \mathrm{~b}$ \\
Killed sod & Daily & $951 \mathrm{a}$ & $302 \mathrm{a}$ & $15.4 \mathrm{a}$ & $0.07 \mathrm{a}$ \\
& $-0.03 \mathrm{MPa}$ & $1049 \mathrm{a}$ & $375 \mathrm{a}$ & $15.1 \mathrm{a}$ & $0.07 \mathrm{a}$ \\
\hline
\end{tabular}

${ }^{7}$ Mean separation within columns by Duncan's multiple range test, $P \leq 0.05$. 


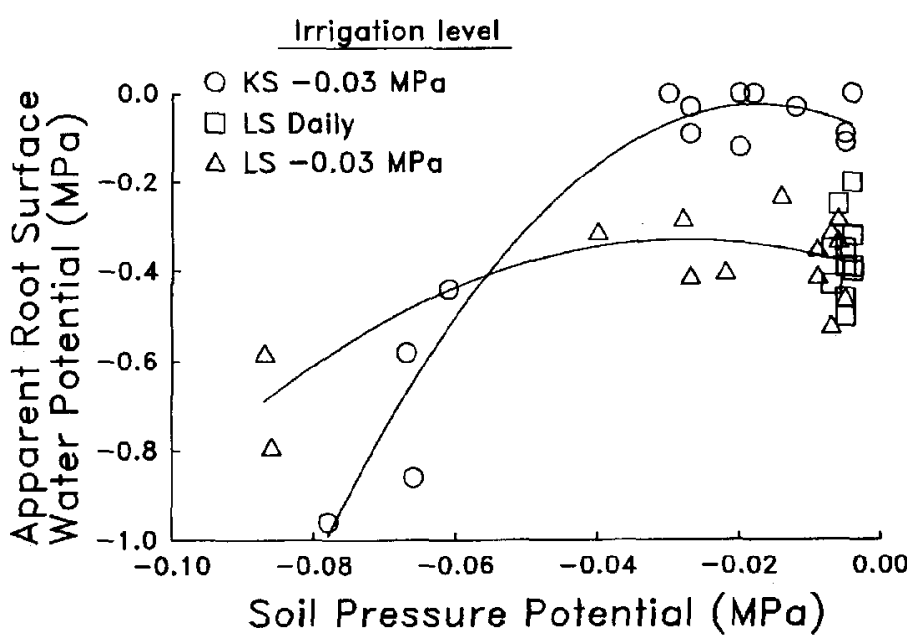

Fig. 2. Relationship between the apparent root surface water potential of peach roots and soil water potential in the presence or absence of a uniform cover of $\mathrm{K}$ 31 tall fescue. KS irrigated at $-0.03 \mathrm{MPa}: \mathrm{y}=-0.1-9.1(\mathrm{x})-262.4\left(\mathrm{x}^{2}\right), r^{2}=0.94$. LS irrigated at $-0.03 \mathrm{MPa}: \mathrm{y}=-0.4-5.6(\mathrm{x})-102.0\left(\mathrm{x}^{2}\right), r^{2}=0.65$. LS irrigated daily: mean $=-0.4 \mathrm{MPa}$.

that the soil cover on $50 \%$ of the root zone can influence root growth, water use, and $\mathrm{NO}_{3}-\mathrm{N}$ levels in the remaining $50 \%$ of the root zone, depending on the competitiveness and soil characteristics of the treatments. These previous results and those of Studies 1-3 indicate a high degree of interaction and compensation between different regions of the root system. Other work demonstrated that a range of species can transfer water within the root system and even exude water into the soil (Breazeale, 1930; Breazeale and McGeorge, 1953a, 1953b; Richards and Caldwell, 1987). We tested this hypothesis and found that the peach root system does have the ability to transfer water from wet to dry regions through the root system. When a single section of our rhizotron was allowed to dry to -0.06 to $-0.08 \mathrm{MPa}$ while the other three sections were at field capacity and the tree was covered in the afternoon, we found the soil pressure potential would increase 0.001 to $0.002 \mathrm{MPa}$ by the following morning. Data collected on seven dates over a range of soil pressure potentials demonstrated that the slope of the regression relating initial afternoon soil pressure potential to the following morning soil pressure potential was significantly less than 1.0 with a tree, whereas the regression for rhizotrons lacking a tree and root system had a slope of 1.0 (Fig. 4). The difference in slope indicated a movement of water from wet regions to dry regions through the root system. Based on the soil

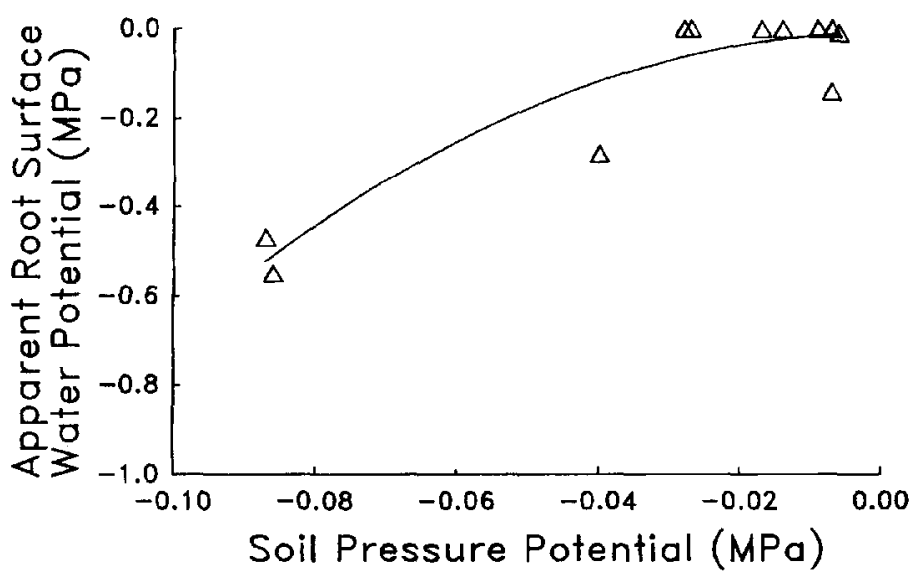

Fig. 3. Relationship between the apparent root surface water potential of K-31 tall fescue roots and soil water potential. $\mathrm{y}=-0.01-0.09(\mathrm{x})-68.76\left(\mathrm{x}^{2}\right), r^{2}=0.87$.
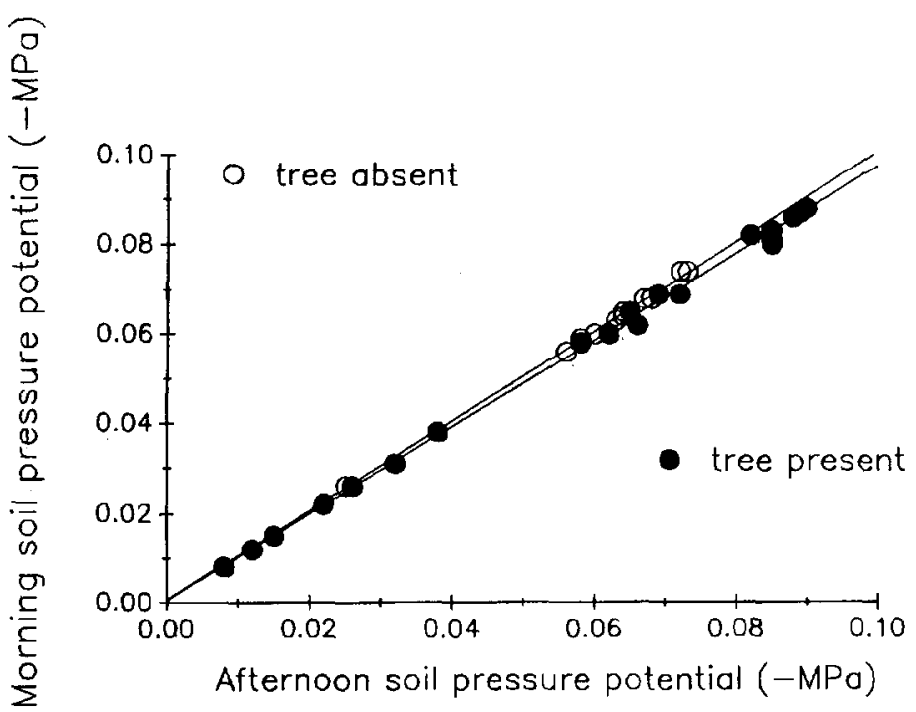

Fig. 4. Relationship of soil water potential in the afternoon and the following morning for nontranspiring trees in 1990. Tree absent: $y=0.001+1.000(x), r^{2}$ $=0.999$. Tree present: $\mathrm{y}=0.001+0.969(\mathrm{x}), r^{2}=0.999$.

water release curve of the Hagerstown silt loam and a soil volume of $39,000 \mathrm{~cm}^{3}(15 \times 50 \times 52 \mathrm{~cm}$; dimensions of each root zone section in our split-root rhizotron), a $0.001-\mathrm{MPa}$ increase in soil pressure potential at a $-0.06 \mathrm{MPa}$ soil pressure potential represents an influx of $58.5 \mathrm{ml}$ of water over $16 \mathrm{~h}$. The mean root length density for the dry root zone sections was $5.98 \mathrm{~cm} \cdot \mathrm{cm}^{-3}$ or $\approx 233,000$ $\mathrm{cm}$ of root length. If the average root diameter is assumed to be 0.5 $\mathrm{mm}$, the root system would have a surface area of $\approx 36,600 \mathrm{~cm}^{2}$ and the exudation of $58.5 \mathrm{~cm}^{3}$ water would develop a water film 0.016 mm thick.

Study 5. The slope of the regression of the 0700 HR water potential on the previous days $1700 \mathrm{HR}$ water potential was significantly less than 1.0 (Fig. 5), confirming that water is transferred from regions of high water availability to regions of low availability through the root. Soil removal on $17 \mathrm{Dec}$. did not alter the relationship of soil water potential at 0700 and $1700 \mathrm{HR}$, confirming that water was not moving through the soil into the dry section.

"Hydraulic lift" (Richards and Caldwell, 1987) of water is an important mechanism that peach uses to support root growth and development in less-than-optimal soil environments. Hydraulic
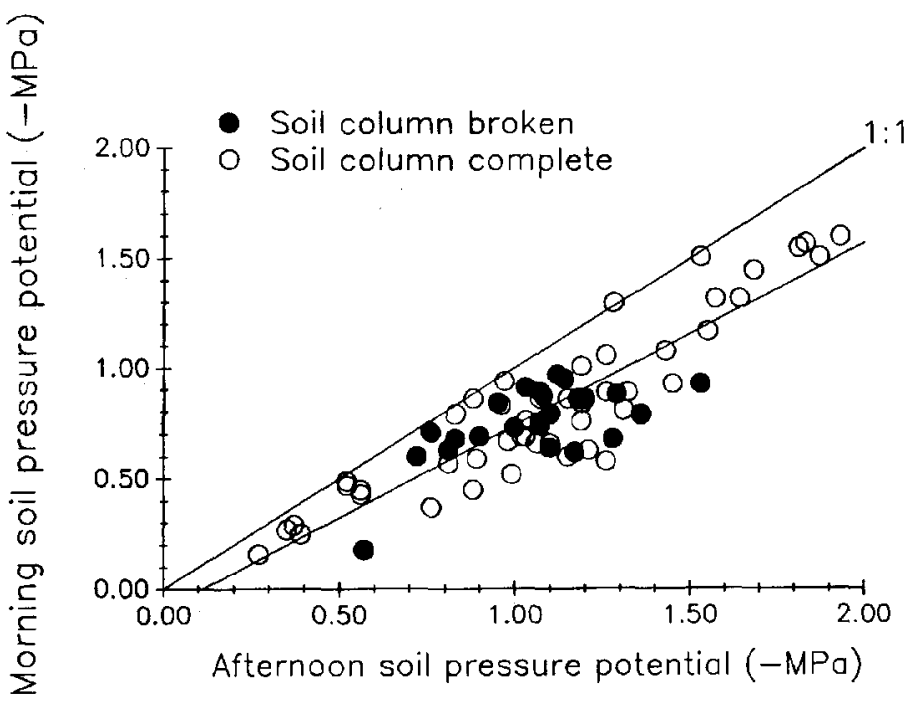

Fig. 5. Relationship of soil potential in the afternoon and the following morning for nontranspiring trees in 1991. $y=0.83(x)-0.01, r^{2}=0.81$. 
lift during the night or periods of low transpiration serves several adaptive purposes: 1) A greater reservoir of soil water is available when water is exuded into drier soil regions and then reabsorbed during the day than would be available from the few roots located in deep, moist soil. 2) A large percentage, if not all, available nutrients are held in the surface layer of the soil. Nambiar (1976, 1977) has demonstrated that hydraulic lift of water from moist to dry soil regions through the root system would facilitate micronutrient uptake. 3) The transfer of water into dry soil regions will reduce water deficits in root tissue and potentially maintain organisms associated with the root system such as mycorrhizae and other microbial associations.

We conclude that reduction of root water deficits by intra-root transfer is the basis for the difference in RLD between Studies 1 and 3. In Study 1, there was apparently sufficient water movement via the root system from the BS treatment into the LS treatment that root initiation was not reduced by the presence of K-31 tall fescue. However, in Study 3, peach roots were apparently always under stress in the presence of a complete cover of $\mathrm{K}-31$, and this inhibited root initiation and root development (Table 2).

Interspecific competition between peach and K-31 tall fescue is a complex system. K-31 tall fescue expresses dominance by extracting soil water and nutrients (Glenn and Welker, 1991), thus interfering with the growth of the peach root system. Peach, however, does have adaptive mechanisms, such as intra-root water transfer, to make efficient use of the root-zone resources and moderate the competitive capacity of K-31 tall fescue.

\section{Literature Cited}

Atkinson, D. 1983. The growth, activity and distribution of fruit tree root system. Plant \& Soil 71:23-35.
Breazeale, E. L. and W.T. McGeorge. 1953a. Exudation pressure in roots of tomato plants under humid conditions. Soil Sci. 75:293-298.

Breazeale, E.L. and W.T. McGeorge. 1953b. Influence of atmospheric humidity on root growth. Soil Sci. 76:361-365.

Breazeale, J.F. 1930. Maintenance of moisture equilibrium and nutrition of plants at and below the wilting percentage. Ariz. Agr. Expt. Sta. Tech. Bul. 29:137-177.

Glenn, D.M. and W.V. Welker. 1989. Peach root development and tree hydraulic resistance under tall fescue sod. HortScience 24: 117-119.

Glenn, D.M. and W.V. Welker. 1991. Soil management affects shoot and root growth, nutrient availability, and water uptake of young peach trees. J. Amer. Soc. Hort. Sci. 116:238-241.

Jones, H.G. 1983. Estimation of au effective soil water potential at the root surface of transpiring plants. Plant, Cell \& Environ. 6:671-674.

Nambiar, E.K.S. 1976. Uptake of $Z^{65}$ from dry soil by plants. Plant \& Soil. 44:267-271.

Nambiar, E.K.S. 1977. The effects of the water content of the topsoil on micronutrient availability and uptake in a siliceous sandy soil. Plant \& Soil. 46:175-183.

Putnam, A.R. and C.S. Tang (eds). 1986. The science of allelopathy. Wiley, New York.

Richards, J.H. and M.M. Caldwell. 1987. Hydraulic lift-substantial nocturnal water transport between soil layers by Artemisia tridentata roots. Oecolgia (Berlin) 73:486-489.

Skroch, W.A. and J.M. Shribbs. 1986. Orchard floor management: An overview. HortScience 21:390-394.

Smucker, A.J.M., S.L. McBurney, and A.H. Srivastava. 1982. Quantitative separation of roots from compacted soil profiles by the hydropneumatic elutriation system. Agron. J. 74:500-503.

Tennant, D. 1975. A test of a modified line intersect method of estimating root length. J. Ecol. 63:995-1001.

Welker, W.V. and D.M. Glenn. 1989. Sod proximity influences the growth and yield of young peach trees. J. Amer. Soc. Hort. Sci. 114:856859. 